\section{Medical Principles}

and Practice
Akhtar, S. 1

Albert, M.J. 1

Al-Sabah, S. 15

Babiker, F.A. 22

Badr, H.E. 29

Barakat, R. 3
Lakha, S.F. 29

Mailis-Gagnon, A. 29

Pennefather, P. 29

Redzic, Z. 3

\title{
Subject Index Vol. 25, Suppl. 1, 2016
}

Blood-brain barrier 3

Cerebral ischemia 3

Chronic non-cancer pain 29

Cytokines 3

Dimerization 15

G protein-coupled receptor 15

Glucagon-like peptide-1 15

Glucose-dependent insulinotropic polypeptide 15
Incretin 15

Internalization 15

Ischemia reperfusion 22

Kuwaiti health system 29

Macrophages 3

Microglia 3

Pacing postconditioning 22

Pain services and management 29

Postconditioning 22

Stroke 3 